\title{
How much can the number of jabiru stork (Ciconiidae) nests vary due to change of flood extension in a large Neotropical floodplain?
}

\author{
Guilherme Mourão', 2; Walfrido Tomas \& Zilca Campos ${ }^{1}$ \\ ${ }^{1}$ Laboratório de Vida Selvagem, Embrapa Pantanal. Caixa Postal 109, 79320-900 Corumbá, MS, Brazil. \\ ${ }^{2}$ Correspondent author. E-mail: gui@cpap.embrapa.br
}

\begin{abstract}
The jabiru stork, Jabiru mycteria (Lichtenstein, 1819), a large, long-legged wading bird occurring in lowland wetlands from southern Mexico to northern Argentina, is considered endangered in a large portion of its distribution range. We conducted aerial surveys to estimate the number of jabiru active nests in the Brazilian Pantanal $\left(140,000 \mathrm{~km}^{2}\right)$ in September of 1991-1993, 1998, 2000-2002, and 2004. Corrected densities of active nests were regressed against the annual hydrologic index (AHI), an index of flood extension in the Pantanal based on the water level of the Paraguay River. Annual nest density was a non-linear function of the AHI, modeled by the equation $6.5 \cdot 10^{-8} \cdot \mathrm{AHI}^{1.99}$ (corrected $\left.r^{2}=0.72, n=7\right)$. We applied this model to the AHI between 1900 and 2004 . The results indicate that the number of jabiru nests may have varied from about 220 in 1971 to more than 23,000 in the nesting season of 1921, and the estimates for our study period (1991 to 2004) averaged about 12,400 nests. Our model indicates that the inter-annual variations in flooding extent can determine dramatic changes in the number of active jabiru nests. Since the jabiru stork responds negatively to drier conditions in the Pantanal, direct human-induced changes in the hydrological patterns, as well as the effects of global climate change, may strongly jeopardize the population in the region.
\end{abstract}

KEY WORDS. Flood; jabiru nesting; Jabiru mycteria; Neotropical wetlands; Pantanal.

The jabiru stork, Jabiru mycteria (Lichtenstein, 1819) is a large, long-legged wading bird occurring in lowland wetlands from southern Mexico to northern Argentina (Hancock et al. 1992, STotz et al. 1996, SicK 1997). AnTAS \& NASCIMENTO (1996) recognized three main populations of this species: the Central American, northern South American, and central South American populations. The population from Central America was considered endangered during the 90s, when only a few dozens of nests were regularly reported (ANTAS \& NASCIMENTO 1996). In Brazil, the species is considered locally extinct in several of the eastern river basins, rare in most of the country's eastern and southern states, and abundant in the Amazonian region and in the Pantanal wetland (ANTAS \& NASCIMENTO 1996). The species is also common in the Llanos of Venezuela, in the Beni floodplains of Bolivia, and in the wetlands of the Paraná and La Plata rivers in Brazil, Paraguay, and Argentina (HANCock et al. 1992, Antas \& Nascimento 1996). Nowadays, the species is recognized as being of least concern by IUCN (BIRD LIFE INTERNATIONAL 2009).

Jabiru storks feed on several aquatic animal species, especially fish, while wading in shallow waters of flooded grasslands, freshwater ponds, rivers, and other types of wetlands (SICK 1997). Nesting occurs during the dry season in the Pantanal, from July to November, when most fledglings leave their nests after nearly six months of parental care (ANTAS \&
NASCimento 1996). Jabiru storks are not colony nesters. Nests are built away from other nests, on branches of large trees such as Tabebuia impetiginosa (Martius ex de Candolle) Standley, 1936 (Bignoniaceae) and Sterculia apetala (Jacquin) Karsten, 1862 (Malvaceae) (Antas \& Nascimento 1996). The nests are large, measuring $1.76 \pm 0.7 \mathrm{~m}$ in diameter, and are built $12.6 \pm 3.4 \mathrm{~m}$ above the ground (Antas \& Nascimento 1996). They are conspicuous due to their large size and the fact that they are built on trees with open-branched canopies, which facilitate the jabiru's landing (Fig. 1).

As in many other seasonal tropical floodplains, the Pantanal has a dry and a wet phase each year (Junk et al. 2006a). Water may be limiting during the dry season, especially in dryer years. However, as the general slope in the Pantanal is $2-3 \mathrm{~cm} /$ $\mathrm{km}$ from north to south, and $5-25 \mathrm{~cm} / \mathrm{km}$ from east to west (Alvarenga et al. 1984), river overbanking and rainfalls cause extensive flood, thus creating large scale, shallow aquatic habitats during the wet season. The draining is gradual and the floods last 4-6 months after the end of the rainy season (Hamilton et al. 1996), but may last longer in wetter years.

Junk et al. (2006b) stated that the floods in the Pantanal create several types of wetlands, which are highly productive habitats for a myriad of fish, amphibians and other aquatic organisms, providing food for several large wading bird species. Consequently, the availability of aquatic habitats and food for 
wading birds is higher, and last longer, in wet years when compared with dry years. In fact, jabiru nests have been found to be active every year (ANTAS \& NASCIMENTo 1996, GonZÁlez 1996) or every other year (CAmpos \& Coutinho 2004, Antas \& Nascimento 1996), depending on habitat conditions (González 1996). Since Ciconiforms generally forage in relatively shallow water (SICK 1997), they synchronize their nesting with the draining stage of seasonal wetlands (DAvid 1994, Gonzalez 1996, BarNhill et al. 2005) to warrant food supply during the period of reproduction (Frederick \& OGden 2001). Therefore, the abundance and reproductive performance of the jabiru stork are expected to be related to the extent of floods and the hydrological characteristics of the major wetlands in which this bird occurs.

The aim of this study was to investigate the temporal variation in the jabiru stork nest density in the Pantanal wetland and its relationship with the flood extension in the region. We hypothesized that flooding extension affects positively the Jabiru nest densities in the Pantanal, resulting in large variations in the number of active nests among years.

\section{MATERIAL AND METHODS}

The Pantanal is a large wetland $\left(\sim 160,000 \mathrm{~km}^{2}\right)$ located in central South America (Brazil, Bolivia and Paraguay), with nearly 140,000 km² of its area in Brazil (SiLva \& AbDon 1998, Junk \& CunHa 2005). The floodplains occupy about one third of the Paraguay River hydrographic basin (SILVA \& ABDon 1998), and the most distinct characteristics of this region are low altitude (75 to $200 \mathrm{~m}$ a.s.l.), flatness, alternated periods of flood and drought, high annual thermal amplitudes, and strong seasonality in precipitation (HARRIs et al. 2005). There is also interannual variation in flood intensity (MOURÃo et al. 2002, JUNK et al. 2006b) resulting from consecutive years of high precipitation followed by years of less intense rainfall (DA SILVA \& GIRAD 2004, HarRis et al. 2005).

Aerial survey was used to estimate the density of jabiru nests along transects covering the Pantanal wetland in Brazil, between parallels $16^{\circ}$ and $20^{\circ} \mathrm{S}$ (about $140,000 \mathrm{~km}^{2}$ ), in September of 1991, 1992, 1993, 1998, 2000, 2001, 2002, and 2004. The surveys were designed to monitor the marsh deer, Blastocerus dichotomus (Illiger, 1815), pampas deer, Ozotoceros bezoarticus (Linnaeus, 1758), and yacare caiman, Caiman yacare (Daudin, 1801), populations (see Mourão et al. 2000), as well as active nests of the jabiru stork. As the jabirus reuse nests for many nesting seasons, we attempted, in each survey, to detect whether each nest was active or not. We considered a nest active when hatchlings, eggs, or adults were observed in the nests. This assessment was possible due to the white, conspicuous color of the large eggs or nestlings that contrast sharply with the brownish color of the nest background. Additionally, most nests were built on large deciduous Tabebuia (Gomez ex de Candolle, 1838) or Sterculia (Linnaeus, 1753) trees (Antas \& NAScimento 1996), which are usually leafless (Fig. 1) by September in the Pantanal
(Pотт \& Pотт 1994), coinciding with the peak of the jabiru nesting season. All counts were made from a fix-winged aircraft (Cessna 182 or Cessna 206) flying $61 \mathrm{~m}$ above the ground at 200 $\mathrm{km} / \mathrm{h}$. Nests were counted in a $200 \mathrm{~m}$ wide strip at ground level, which was delimited by a rod with reference marks in the airplane. Transects were spaced six geographic minutes from one another during the 1991-1993 surveys, and about 12 geographic minutes in the later surveys. Sampling intensity was defined as the ratio of the area actually sampled (i.e., the sum of the strip transect areas) and the total area surveyed. As the transect lengths were unequal and their numbers varied among the years, the resulting sample intensities ranged from $1.4-1.7 \%$ in the $1991-$ 1993 , and $0.7-0.8 \%$ in the later surveys.

The double-count technique, a method derived from the Lincoln-Petersen estimate (Magnusson et al. 1978, Caughley \& Grice 1982, Bayliss \& Yeomans 1989, Grahan \& Bell 1989, Potvin et al. 2004) was used to improve the accuracy of the estimates. In this technique, two observers placed at the same side of the airplane conducted independent counts, and each transect was divided into subunits of approximately $3 \mathrm{~km}$ in which sightings were recorded. By comparing the records of both observers in each sub-unit, we separated the nests into three categories: B (sighted by both observers), $\mathrm{S}_{1}$ (sighted only by observer 1 ), and $S_{2}$ (observed only by observer 2 ). The detection probability (P) was obtained according Graham \& Bell (1989). Then, the multiplicative correction factor for the counts was estimated as $\mathrm{CF}=1 / \mathrm{P}$ and was applied to the total number of nests recorded in each transect $\left(\mathrm{S}_{1}+\mathrm{S}_{2}+\mathrm{B}\right)$ to obtain the corrected counts (y) (Graham \& Bell 1989). We estimated corrected nest abundance $(\mathrm{Y})$, corrected density (D), and their standard errors (SE) using the equations of SINCLAIR et al. (2006) for sample units of different sizes and without replications.

We obtained an annual hydrologic index (AHI) (VALDERRAMA \& Petrere 1994) as the sum of the daily Paraguay River water level (in meters) measured at Ladário, Mato Grosso do Sul, Brazil $\left(57^{\circ} 35^{\prime} \mathrm{W}, 19^{\circ} 00^{\prime} \mathrm{S}\right)$. The data recorded at Ladário is especially convenient for our analyses, as it correlates with the flooded area of the Pantanal (Hamilton et al. 1996). Then, AHI express the extension and duration of the floods in the Pantanal. Because our surveys always took place in early September, coinciding with the peak of the jabiru stork nesting period, our "hydrologic year" started every September $1^{\text {st }}$ of the previous year and ended on August $31^{\text {st }}$ of the modeled year. Also, we examined the Pearson correlation between the AHI and its corresponding 24-month hydrologic index (i.e., the summation of the given AHI with a preceding one). This is a precaution we adopted, as there were reports of bi-annual nesting cycles by jabiru storks (Antas \& Nascimento 1996, Campos \& Coutinho 2004).

We used the NONLIN procedure of Systat 11 (Systat Inc. 2004 , Illinois) to iteratively estimate parameters a and b of the model $\mathrm{D}=\mathrm{a} \cdot \mathrm{AHI}^{\mathrm{b}}$, where $\mathrm{D}$ is the corrected jabiru nest density. We identified one outlier corresponding to the 1998 survey, a year in which the Tabebuia trees sprouted early, resulting 


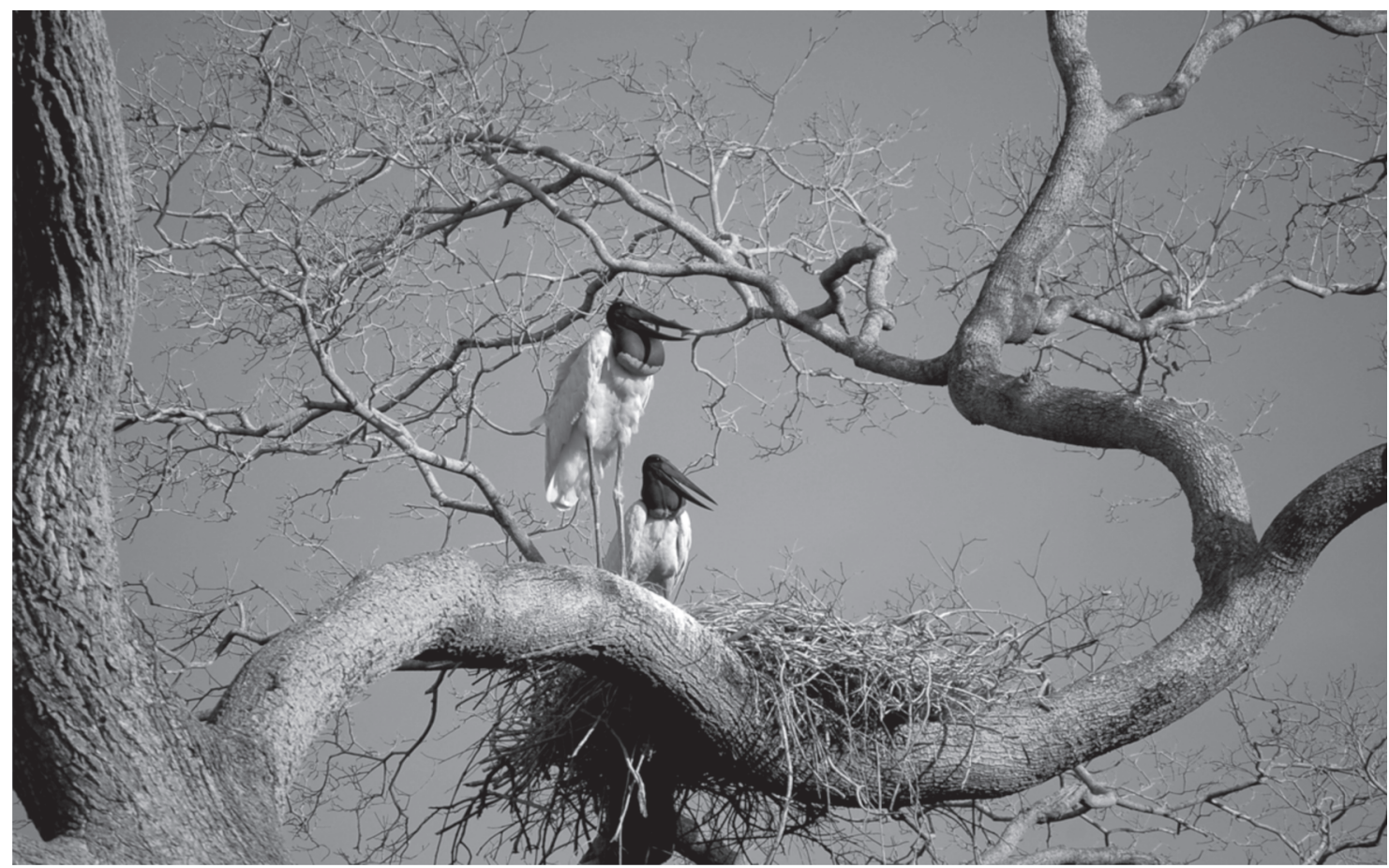

Figure 1. Jabiru stork nest built on a T. impetiginosa tree in the Pantanal of Brazil, showing a mating pair. Photo by Caroline Leuchtenberger.

in a lower nest visibility from the air. We excluded this point and re-ran the analysis. The resulting models were used to retrospectively estimate the abundance of nests based on the historical data-set of the Paraguay River level at Ladário (1900 to 2004). Finally, we compared the abundance estimates obtained from the models, including and excluding the outlier, using the Kolmogorov-Smirnoff two-sample test (KS).

\section{RESULTS}

In the historical series comprising the period from 1900 to 2004 , the AHI varied about ten-fold from its minimum to its maximum in the Pantanal, ranging from $165.5 \mathrm{~m}$ in 1971 to $1654.1 \mathrm{~m}$ in 1921 (Fig. 2), with a mean of $989.3 \mathrm{~m}$ (SD = $364.0 \mathrm{~m}$ ). The period from 1962 to 1973 was unusually dry, and was fol-

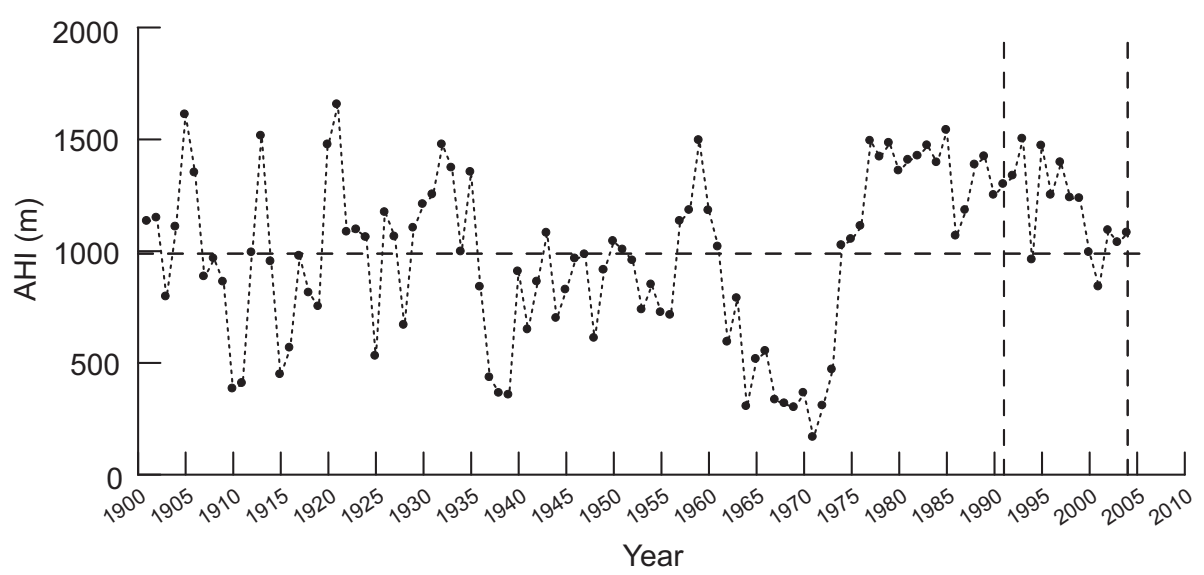

Figure 2. Temporal series of an Annual Hydrologic Index (AHI) based on the water level of the Paraguay River measured in Ladário, Mato Grosso do Sul, Central Brazil. The horizontal dashed line indicates the historical AHI mean. Our study period was comprised between 1991 and 2004 and is indicated by the vertical dashed lines. 
lowed by a contrastingly long wet period. The AHI ranged from 960 to $1500 \mathrm{~m}$ during our study period (1991-2004). Considering the whole series of river level measurements (1900-2004), the AHI was highly correlated with the 24-month hydrologic index $(r=0.92)$.

Annual nest density was a nonlinear function of the AHI (Fig. 3), with the model $6.5 \cdot 10^{-8} \cdot \mathrm{AHI}^{1.99}$ returning a mean corrected $\mathrm{r}^{2}$ (estimated as 1-residual/corrected) equal to 0.72 $(n=7)$. The inclusion of the outlier (1998 estimate) in the data set produced the model $1.6 \cdot 10^{-8} \cdot \mathrm{AHI}^{2.17}$ with a smaller mean corrected $\mathrm{r}^{2}(0.48, \mathrm{n}=8)$. However, the estimates of total number of jabiru nests in the Pantanal did not differ between the models (KS, maximum difference of cumulative distributions $=0.011, \mathrm{P}=0.493$ )

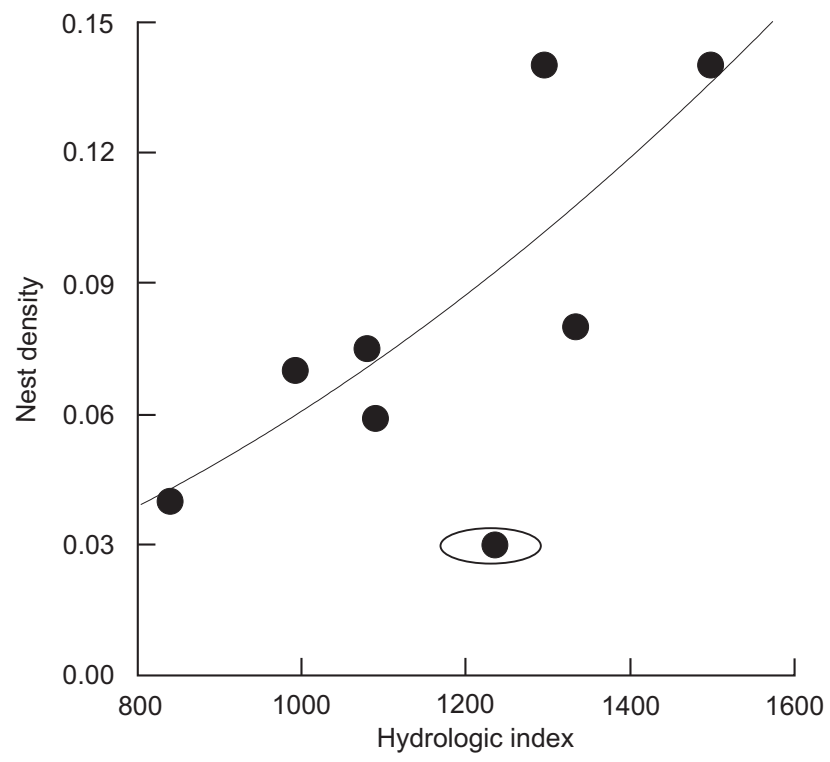

Figure 3. Relationship between jabiru stork nest density (nest $/ \mathrm{km}^{2}$ ) in the Pantanal wetlands and the Annual Hydrologic Index (AHI) based on the Paraguay River level measured at Ladário, Mato Grosso do Sul, Brazil. An outlier point relative to the year of 1998, when conditions of poor nest visibility prevailed, is indicated by an ellipsis. The line indicates a curvilinear relationship described by the equation: Nest density $=6.5 \cdot 10^{-8} \cdot \mathrm{AHI}^{1.99}$.

Therefore, we used the first model to estimate the number of jabiru nests in the Pantanal each year, using the AHI obtained from the historical series of river level measurements (Fig. 4). The results indicate that the number of jabiru nests in the Pantanal may have been as low as 220 in 1971, and as high as 23,370 in the nesting season of 1921 . The average number of nests estimated for our aerial survey period (1991 to 2004) was $12,400(5,942-19,186)$.

\section{DISCUSSION}

Our model is simple and does not take into account complex feedback processes expected to occur in population dynamics (e.g., Sinclair et al. 2006). However, our goal was not to build an accurate model to predict the number of jabiru nests from a single factor. Instead, we examined the magnitude of change in nest density in a scenario of natural or artificial changes in flooding extension affecting large wetlands such as the Pantanal. The nesting interval of jabirus did not restrict our modeling approach, since the AHI and the 24-month HI were highly correlated in the Pantanal. Our model indicates that the multiyear variations in the flooding extent may determine dramatic changes in jabiru nest numbers in the Pantanal. It also indicates that, during the long dry period of the 1960s and early 1970s, the number of jabiru nests in the Pantanal may have fallen to nearly 200, as estimated from our density model applied to the whole area covered by the surveys (i.e., $140,000 \mathrm{~km}^{2}$ ). In the same period, the average number of nests was estimated to be about 1,700. During the period in which we surveyed jabiru nests in the Pantanal (1991-2004), active nest abundance was estimated to be relatively high, and at least 30,000 reproductive individuals may have inhabited the Pantanal.

The AHI varied about ten-fold from its minimum to its maximum in the Pantanal, with multiyear fluctuations determining severe drought or severe flood conditions prevailing for relatively long periods. In fact, during the last three decades the floods in the Pantanal were relatively more intense than in former decades, but with an apparent tendency to decrease. However, these within-century fluctuations in flood conditions should be considered part of a larger picture, since the Pantanal seems to have passed through different climate episodes in the Holocene period: 40,000-8000 BP cool and dry, 8000-3500 BP warm and wet, 3500-1500 BP warm and dry and 1500 BP-present warm and wet (JuNK et al. 2006b). Considering the large variation in the estimated nest numbers during the favorable climate period (warm and wet) that prevailed during the $20^{\text {th }}$ century, it is reasonable to argue that the jabiru may have been absent from the Pantanal during most of the last 40,000 years. This scenario implies that the conservation of such a wetland-dependent species should be approached in large temporal and spatial scales that may include all major wetlands in the continent.

Large-scale direct human interventions may cause strongly negative impacts on jabiru stork conservation. Hamilton (1999) pointed out that interventions in the Paraguay River channel to improve navigation, such at those planned for the "Paraguay Hydrovia Project", may change the pattern and extent of flooding in the Pantanal. The Hydrovia project was officially abandoned by the Federal Government in 1996, but the construction of dams in headwaters of the rivers that flow through the Pantanal now poses 


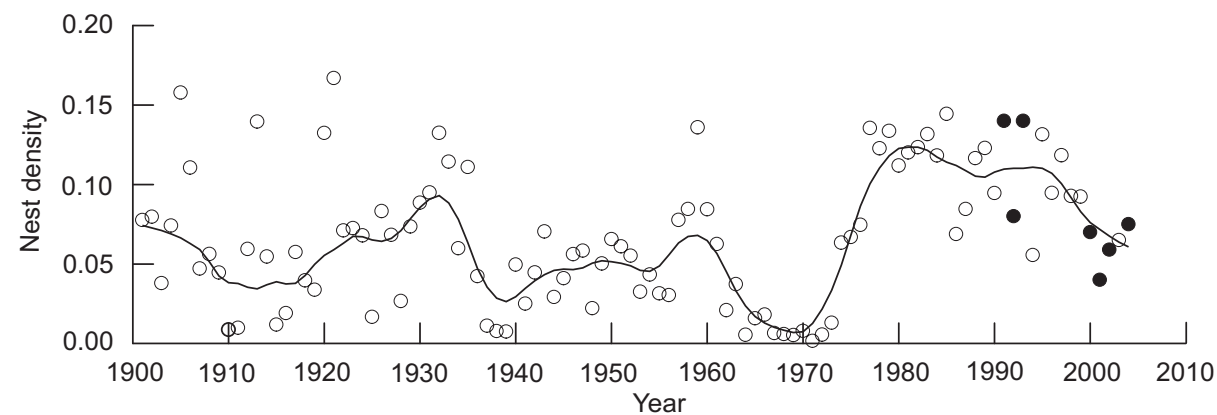

Figure 4. Reconstituted annual jabiru nest density in the Pantanal (empty circles), modeled as: Nest density $=6.5 \cdot 10^{-8} \cdot \mathrm{AHI}^{1.99}, \mathrm{where}^{-6}$ $\mathrm{AHI}$ is an index of the annual flooding intensity of the whole Pantanal, based on a historical series of river level measurements from 1900-2004. Solid circles are annual jabiru nest densities estimated from aerial surveys covering the Pantanal of Brazil, between parallels $16^{\circ}$ and $20^{\circ}$ S, in September of 1991, 1992, 1993, 1998, 2000, 2001, 2002, and 2004. The line was a LOWESS smooth adjusted with a tension $=0.1$ (Systat 11, Systat Inc. 2004, Illinois).

a major threat. Since 2002, a $212 \mathrm{MW}$ power station in the Manso River has been in operation, which has resulted in an artificial lake of about $420 \mathrm{~km}^{2}$. This dam has already changed the hydrology of the Cuiabá River (Junk et al. 2006b), the most important tributary of the Paraguay River. Recently, the Government has allowed the construction of 44 small dams for hydroelectric production purposes (0.12 to 29.1 $\mathrm{MW}$ ), and there are plans to build additional 71 dams along the headwaters of the tributaries of the Paraguay River. The potential impact of each of these individual plants is relatively small, but pooled together they may severely alter the flood pulse in the Pantanal. This type of change in the ecosystem may affect directly the number of jabiru nests in the floodplain, given the strong relationship between water availability, flood regime and nesting by the jabiru stork. It is not unlikely that other animal species that are highly dependent on the floods, such as the yacare caiman (CAmpos \& MAgnusson 1995) or the endangered marsh deer (Tomas et al. 2001) would be negatively affected by such a large-scale environmental change.

Global climate change projections for the Pantanal region indicate a two-month delay in the rainy season (MARENGO 2007). Some scenarios also suggest a $0.5 \mathrm{~mm}$ /day reduction in rainfall, as well as negative anomalies (severe decrease in rainfall) after 2060 , and a $3-6^{\circ} \mathrm{C}$ increase in the average temperature (MARENGO 2007). Although these models are not conclusive, they suggest changes that may lead to a strong impact in the characteristics of the floods in the Pantanal. Our predictions, based on historical records of the Paraguay River levels, show that extended dryer periods would severely affect the number of jabiru nests in the Pantanal. Consequently, the population of this species may be in jeopardy in the future. It will be of special concern if both threats, dams and climate change, conjugate to deeply change the functioning of the Pantanal wetlands.

\section{ACKNOWLEDGMENTS}

This research was supported by the Conselho Nacional de Desenvolvimento Científico e Tecnológico (Proj. PELD/CNPq 520056/98-1), World Wildlife Fund (WWF-USA), Conservação Internacional do Brasil (CI-Brasil) and Projeto de Conservação e Utilização Sustentável da Diversidade Biológica (Probio-MMA 01.02.12). We are grateful to William Magnusson and Beatrice Allain, who improved the English of a draft manuscript. Ubiratan Piovezan helped us count animals during the 2002 survey. Also, we thank the three anonymous reviewers for many contributions that improved the manuscript.

\section{LITERATURE CITED}

Alvarenga, S.M.; A.E. Brasil; R. Pinheiro \& H.J.H. Kux. 1984. Estudo geomorfológico aplicado a Bacia do Alto Paraguai e Pantanais Matogrossenses. Boletim Técnico Projeto RADAM/BRASIL, Série Geomorfologia 187: 89-183.

AnTAS, P.T.Z. \& I.L.S. NASCimento. 1996. Tuiuiú: sob os céus do Pantanal. Biologia e conservação do tuiuiú Jabiru mycteria. São Paulo, Empresa das Artes, 169p.

Barnhill, R.A.; D. Weyer; W.F. Young; K.G. Smith \& D.A. James. 2005. Breeding biology of Jabirus (Jabiru mycteria) in Belize. Wilson Bulletin 117: 142-153.

Bayliss, P. \& K.M. Yeomans. 1989. Correcting bias in aerial survey population estimates of feral livestock in Northern Australia using double count technique. Journal of Applied Ecology 26: 925-933.

BiRd Life InTERnAtionaL. 2009. Jabiru mycteria. In: IUCN (Ed.) IUCN Red List of Threatened Species. Version 2009.2. Avalaible online at: www.iucnredlist.org [Accessed: 18/XII/2009].

Campos, Z. \& M.E. Coutinho. 2004. Levantamento aéreo de ninhos de tuiuiú, Jabiru mycteria, no Pantanal Sul. Boletim de Pesquisa e Desenvolvimento, Embrapa Pantanal 56: 1- 
14. Available online at: www.cpap.embrapa.br/publicacoes/ online/BP56.pdf [Accessed: 11/VIII/2008].

Campos, Z. \& W.E. Magnusson. 1995. Relationship between rainfall, nesting habitat and fecundity of Caiman crocodilus yacare in the Pantanal, Brazil. Journal of Tropical Ecology 11: 351-358.

Caughley, G. \& D. Grice. 1982. A correction factor for counting emus from the air, and its application to counts in Western Australia. Australian Wildlife Research 9: 253-259.

Da Silva, C.J. \& P. Girard. 2004. New challenges in the management of the Brazilian Pantanal and catchment area. Wetlands Ecology and Management 12: 553-561.

DAvID, P.G. 1994. Wading birds nesting at Lake Okeechobee, Florida: an historical perspective. Colonial Birds 17: 6977.

Frederick, P.C. \& J.C. Ogden. 2001. Pulsed breeding of longlegged wading birds and the importance of infrequent severe drought conditions in the Florida Everglades. Wetlands 21: 484-491.

GonŹ́LEZ, J.A. 1996. Breeding biology of the jabiru in the southern Llanos of Venezuela. Wilson Bulletin 108: 524534.

Graham A. \& R. Bell. 1989. Investigating observer bias in aerial survey by simultaneous double-counts. Journal of Wildlife Management 53 (4): 1009-1016.

Hamilton, S.K. 1999. Potential effects of a major navigation project (Paraguay - Paraná hydrovia) on inundation in the Pantanal floodplains. Regulating Rivers: Research of Management 15: 289-299.

Hamilton, S.K.; S.J. Sippel \& J.M. Melack. 1996. Inundation patterns in the Pantanal wetland of South America determined from passive microwave remote sensing. Archives fur Hydrobiology 137: 1-23.

Hancock, J.A.; J.A. Kushlan \& M.P. Kahl. 1992. Storks and spoonbills of the world. London, Academic Press, 385p.

Harris, M.; W. Tomás; G. Mourão; C.J. Da Silva; E. Guimarães; F. Sonoda \& E. FACHim. 2005. Safeguarding the Pantanal wetlands: threats and conservation initiatives. Conservation Biology 19: 714-720.

Junk, W.J. \& C.N. CunHa. 2005. Pantanal: a large South American wetland at a crossroads. Ecology Engineering 24: 391-401.

Junk, W.J.; M. Brown; I.C. Campbell; M. Finlayson; B. Gopall; L. RAMBERG \& B.G. WARNER. 2006a. The comparative biodiversity of seven globally important wetlands: a synthesis. Aquatic Sciences 68: 400-414.

Junk, W.J.; C.N. Cunha; K.M. Wantzen; P. Petermann; C.
Strussmann; M.I. Marques \& J. Adis. 2006b. Biodiversity and its conservation in the Pantanal of Mato Grosso, Brazil. Aquatic Sciences 68: 278-309.

Magnusson, W.; G.J. Caughley \& G.C. Grigg. 1978. A double survey estimate of population size from incomplete counts. Journal of Wildlife Management 42: 174-176.

Marengo, J.A. 2007. Mudanças climáticas globais e seus efeitos sobre a biodiversidade - Caracterização do clima atual e definição das alterações climáticas para o território brasileiro ao longo do Século XXI. Brasilia, Ministério do Meio Ambiente, $2^{\text {nd }}$ ed., 201p.

Mourão, G.; M.E. Coutinho; R.A. Mauro; Z. Campos; W. Tomás \& W.E. Magnusson. 2000. Aerial survey of caiman, marsh deer and pampas deer in the Pantanal Wetland of Brazil. Biological Conservation 92: 175-183.

Mourão, G.; M.D. Oliveira; D.F. Calheiros; C.R. Padovani; E.J. Marques \& M. Uetanabaro. 2002. O Pantanal mato-grossense, p. 29-49. In: U. Seedliger; C. Cordazzo \& F. Barbosa (Eds). Os sites e o programa brasileiro de pesquisas ecológicas de longa duração. Belo Horizonte, CNPq, 184p.

Pотт, A. \& V.J. Ротт. 1994. Plantas do Pantanal. Embrapa, Brasília, 320p.

Potvin, F.; L. Breton \& L.P. Rivest. 2004. Aerial surveys for whitetailed deer with the double-count technique in Québec: two 5-year plans completed. Wildlife Society Bulletin 32: 10991107.

SIck, H. 1997. Ornitologia brasileira. Rio de Janeiro, Editora Nova Fronteira, 862p.

Silva, J.S.V. \& M.M. AbDon. 1998. Delimitação do Pantanal brasileiro e suas sub-regiões. Pesquisa Agropecuária Brasileira 33: $1703-1711$.

Sinclair, A.R.E.; J.M. Fryxell \& G. Caughley. 2006. Wildlife ecology, conservation, and management. Malden, Blackwell Publishing, $2^{\text {nd }}$ ed., 469p.

Stotz, D.F.; J.W. Fitzpatrick; T.A. Parker \& D.K. Moskovits. 1996. Neotropical birds: ecology and conservation. Chicago, University of Chicaco Press, 700p.

Tomas, W.; S.M. Salis; M.P. Silva \& G. MourÃo. 2001. Marsh deer (Blastocerus dichotomus) distribution as a function of floods in the Pantanal wetland, Brazil. Studies of Neotropical Fauna and Environment 36: 9-13.

Valderrama, M.B. \& M. Petrere. 1994. Crecimento del bocachio Prochilodus magdalenae Steindachner 1878 (Prochilodontidae), y su relación con el regimen hidrológico en la parte baja de la cuenca del rio Magdalena (Colombia). Boletim Científico INPA 2: 136-152.

Submitted: 18.VI.2009; Accepted: 27.VI.2010.

Editorial responsibility: Glauco Machado 